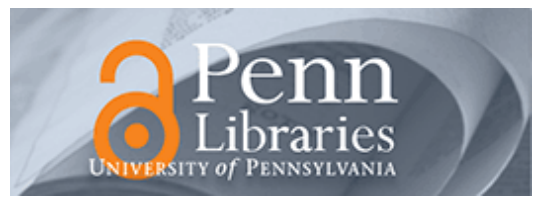

University of Pennsylvania

ScholarlyCommons

$9-2014$

\title{
"Until I Became a Professional, I Was Not, Consciously, Indigenous": One Intercultural Bilingual Educator's Trajectory in Indigenous Language Revitalization
}

Nancy H. Hornberger

University of Pennsylvania, nancyh@gse.upenn.edu

Follow this and additional works at: https://repository.upenn.edu/gse_pubs

Part of the Education Commons

\section{Recommended Citation}

Hornberger, N. H. (2014). "Until I Became a Professional, I Was Not, Consciously, Indigenous": One Intercultural Bilingual Educator's Trajectory in Indigenous Language Revitalization. Journal of Language, Identity \& Education, 13 283-299. http://dx.doi.org/10.1080/15348458.2014.939028

This paper is posted at ScholarlyCommons. https://repository.upenn.edu/gse_pubs/415

For more information, please contact repository@pobox.upenn.edu. 


\title{
“Until I Became a Professional, I Was Not, Consciously, Indigenous”: One Intercultural Bilingual Educator's Trajectory in Indigenous Language Revitalization
}

\begin{abstract}
Drawing from long-term ethnographic research in the Andes, this paper examines one Quechua-speaking Indigenous bilingual educator's trajectory as she traversed (and traverses) from rural highland communities of southern Peru through development as teacher, teacher educator, researcher, and advocate for Indigenous identity and language revitalization across urban, periurban, and rural spaces. Neri Mamani grew up in highland Peru and at the time I met her in 2005 was a bilingual intercultural education practitioner enrolled in master's studies at the Program for Professional Development in Bilingual Intercultural Education for the Andean Region (PROEIB-Andes) at the University of San Simón in Cochabamba, Bolivia. Drawing from my ethnographic research at PROEIB that year, situated also within a broader context of my ethnographic research on bilingual education in the Andes across several decades and Neri's life trajectory across those same decades, this paper analyzes her narrative as it emerged in a 4-hour interview with me. I argue that Neri and her peers' recognizing, valorizing, and studying the multiple and mobile linguistic, cultural, and intercultural resources at play in their own and others' professional practices around bilingual intercultural education enable them to co-construct an Indigenous identity that challenges deep-seated social inequalities in their Andean world.
\end{abstract}

\section{Keywords}

Andes, bilingual intercultural education, ethnography, Indigenous identity, Peru, Quechua, teacher education

Disciplines

Education 
"Until I became a professional, I was not, consciously, Indigenous":

One intercultural bilingual educator's trajectory in Indigenous language revitalization*

Nancy H. Hornberger

University of Pennsylvania

Contact address and email

3700 Walnut Street, Philadelphia, PA 19104-6216, USA

nancyh@upenn.edu 
"Until I became a professional, I was not, consciously, Indigenous":

One intercultural bilingual educator's trajectory in Indigenous language revitalization*

\section{Abstract:}

Drawing from long-term ethnographic research in the Andes, this paper examines one Quechua-speaking indigenous bilingual educator's trajectory as she traversed - and traverses -- from rural highland communities of southern Peru through development as teacher, teacher educator, researcher, and advocate for Indigenous identity and language revitalization across urban, peri-urban, and rural spaces. Neri Mamani grew up in highland Peru and at the time I met her in 2005, was a bilingual intercultural education practitioner enrolled in master's studies at the Program for Professional Development in Bilingual Intercultural Education for the Andean Region (PROEIB-Andes) at the University of San Simón in Cochabamba, Bolivia. Drawing from my ethnographic research at PROEIB that year, situated also within a broader context of my ethnographic research on bilingual education in the Andes across several decades and Neri's life trajectory across those same decades, this paper analyzes her narrative as it emerged in a four-hour interview with me. I argue that Neri and her peers' recognizing, valorizing, and studying the multiple and mobile linguistic, cultural, and intercultural resources at play in their own and others' professional practices around bilingual intercultural education enable them to co-construct an Indigenous 
identity that challenges deep-seated social inequalities in their Andean world.

\section{Key words:}

Andes, bilingual intercultural education, ethnography, Indigenous identity, Peru, Quechua, teacher education

Word count: 8899

\section{Introduction}

¿Es indígena el que vive en el campo, o en la puna, que no tiene acceso a nada de la ciudad o de cosas occidentales? ¿Eso es indígena? Era nuestra pregunta. Y otros decían - también es indígena el que siente en el corazón....Y yo le comentaba a uno de mis compañeros ...que tal vez yo he aprendido a ser indígena, o he tomado consciencia de ser indígena, gracias a una persona que no es indígena, que peleaba por los indígenas, ... la igualdad, la justicia,... una persona metida en educación. Entonces, yo decía... recién allí me he dado cuenta ... hasta una edad, casi hasta ser profesional, no, o sea conscientemente, no estaba de indígena.

Is the Indigenous person one who lives in the countryside, or in the high plain, who has no access to anything from the city or to western ways? Is that an Indigenous person? That was our question. And some were saying whoever feels it in their heart is also Indigenous...And I commented to one of my classmates that maybe I learned to be Indigenous, or became conscious of being Indigenous, thanks to a person who is in fact not Indigenous, ...who 
fought for Indigenous people, ... equality, justice, ... a person involved in education. So, I said ...only then did I realize ... until I reached a certain age, almost until I became a professional, I was not, consciously, Indigenous. (Neri Mamani interview with NHH, June 20, 2005) ${ }^{1}$

Drawing from long-term ethnographic research in the South American Andes, this paper examines one Quechua-speaking Indigenous bilingual educator's trajectory as she traversed - and traverses -- from rural highland communities of southern Peru through development as teacher, teacher educator, researcher, and advocate for Indigenous identity and language revitalization across rural, urban, and peri-urban spaces of the Andes. Neri Mamani grew up in southern highland Peru and, at the time I met her in 2005, was a bilingual intercultural education practitioner enrolled in master's studies at the Program for Professional Development in Bilingual Intercultural Education for the Andean Region (PROEIB-Andes), at San Simón University in Cochabamba, Bolivia. Drawing from my ethnogrfaphic research at PROEIB that year, situated also within a broader context of my ethnographic research on bilingual education in the Andes across several decades and Neri's life trajectory across those same decades, this paper analyzes her narrative as it emerged in a two-hour group interview and four-hour individual interview with me. Throughout, I seek to foreground Neri's own analysis and reflection on her life and her own selfpositioning as an Indigenous person.

Neri's narrative recounts how her early pride in her family's Quechua roots coexisted with rural/urban, Quechua/Spanish, Indigenous/Western 
dichotomies, but later evolved into recognition and advocacy of the importance of using Quechua and maintaining rural Indigenous cultural practices in educational, urban, and employment spheres. She reflects that as a child she lacked a conscious sense of Indigeneity. She grew up in the relatively urban environment of Sicuani, but maintained contact with the rural community of her birth during school vacations, when she and her sisters stayed with their grandparents in Callalli, herding sheep and alpacas. They dressed in the colorful hand-embroidered clothing typical of the region, which they would also automatically change out of when they left Callalli to return to their studies in Sicuani. Thus a sharp distinction between Spanish language, Western dress and urban space on the one hand, and Quechua language, Indigenous dress, the countryside and agricultural work (sheep herding) on the other, existed for Neri as a child, but without a conscious sense that this distinction represented "Indigenousness."

Through her experiences, mobility, studies and work as bilingual teacher, teacher educator, and researcher, those distinctions have gradually blurred in her practices even as her identity has become more consciously Indigenous. Now, she assumes a personal language policy and flexible communicative practice of using Quechua in public, urban, and literate spaces in her daily life in order to break down the dichotomies and their attendant language and identity compartmentalizations. She and her Indigenous peers engage in shared, bordercrossing communicative and cultural practices for varying purposes within and beyond their professional practices around bilingual intercultural education (EIB). Recognizing, valorizing, and studying these multiple and mobile linguistic, 
cultural and intercultural resources are part of what Blommaert (2010) refers to as a critical sociolinguistics of globalization that focuses on language-in-motion rather than language-in-place, an enterprise that Neri and her peers are deeply engaged in and which I, here, seek to describe and further.

Blommaert suggests that globalization forces us to rethink sociolinguistics "as a sociolinguistics of mobile resources, framed in terms of trans-contextual networks, flows, and movements" (2010:1). Following Hymes (1996: 25-62, originally 1980), he posits a "sociolinguistics of 'speech', of actual language resources deployed in real sociocultural, historical and political contexts" (Blommaert 2010: 5). Layered immigrant spaces such as Blommaert's own Antwerp neighborhood --and I would argue also layered migrant spaces such as PROEIB's Cochabamba and its Andean highland environment-- are spaces of local and translocal superdiversity (Blommaert \& Backus 2011, Blommaert \& Rampton 2011, Jørgensen et al. 2011), wherein people possess and deploy multilingual repertoires - complexes of semiotic resources including concrete accents, registers, genres, modalities, bits of language and literacy varieties, including "spoken, vernacular and non-native varieties of different languages, with an overlay of differentially developed literacy skills in one or some languages" (Blommaert 2010: 9, 102). This notion of multilingual repertoire replaces a view of language as "narrowly tied to a community, a time and place" with "a view in which language exists in and for mobility across space and time" (Blommaert 2010: 181), a shift that is particularly meaningful and poignant for present-day speakers of Indigenous languages, as we will explore below. 
Specifically, Blommaert draws on sociolinguistic notions of scale, indexicality and polycentricity to underline the ways in which language, and in particular language-in-motion, relates to power and inequality. Scales, or spatiotemporal frames organized on different, layered scale-levels; indexical distinctions that project minute linguistic differences onto these stratified patterns and convert linguistic/semiotic difference into social inequalities; and polycentricity multilayered complexes of norms and appropriateness criteria centered in authority-- all point to the ways in which language use indexes power relations. Decades of sociolinguistic research and theoretical insight demonstrate that people orient to these layered and hierarchically ordered indexicalities in everyday communication: Gumperz' (1982) contextualization, Goffman's (1974) frames, Bakhtin's (cf. Fairclough 1992) intertextuality, Bourdieu's (1990) habitus, and Silverstein's (2006) presupposed and entailed meanings all identify the jump from one scale to another, token to type, specific to general, individual to collective.

Here, I argue that Neri and her PROEIB peers' critical sociolinguistics of globalization - i.e. their recognizing, valorizing, and studying the multiple and mobile linguistic, cultural and intercultural resources at play in their own and others' professional practices around bilingual intercultural education -- enables them to co-construct Indigenous identities that challenge deep-seated social inequalities in their Andean world. In what follows, I first briefly recount the outlines of Neri's life trajectory and mobility as told in her interview narrative, exploring some of the dimensions of the rural/urban, Quechua/Spanish, Indigenous/Western dichotomies she recalls from her childhood and sees 
reinforced by stereotypes and practices still in play in Peru and the Andes more generally, and introducing the PROEIB context and experience. In the second half of the paper, I take up the emerging conscious sense of Indigenous identity and the linguistic, cultural, and intercultural practices she and her peers at PROEIB engage in, study, and advocate in their research and professional lives. Throughout, I draw primarily on Neri's narrative and my participant observation and interviews at PROEIB in several visits during 2004-2006. I conclude with a brief reflection on what I have learned from spending time with these young Indigenous educational leaders and the privilege it has been to do so.

\section{Neri's life trajectory and mobility}

Neri's family name, Mamani, is a recognizably Indigenous Andean name. Having an Indigenous family name has served as a basis for discrimination in the Andean republics, in response to which many have changed or hispanicized their names to afford greater upward mobility, something Rosaleen Howard terms “onomasiological positioning" (Howard, 2007, pp. 188-189). Neri's father, on the other hand, took pride in his family name and accomplishments, and Neri attributes to her father the sense of confidence and pride she and her three sisters grew up with, within a context where racism was -and is-- a given and where a pejorative Indigenous identity was and is synonymous with having a last name or skin color like hers, with living in the countryside and using nonWestern dress. Yet, for Neri, these were taken-for-granted ways of being, not consciously (or negatively) marked as "Indigenous." 
Neri is the third of four sisters, all of whom are bilingual teachers. Born 12 January 1970 in the remote and sparsely populated highland district of Callalli at 3800 meters altitude in Peru's Arequipa department, she lived most of her life in the southern Peruvian highlands, studying and working in rural districts of Arequipa, Apurimac and Cusco departments, until she moved to the city of Cochabamba, Bolivia in 2004 to begin her PROEIB master's studies. Neri completed her first years of schooling in rural Callalli-- 2 years of pre-school and first grade. When she was 7, her father's work took the family to Sicuani, a small highland city of approximately 15,000 (now 57,500) in neighboring Cusco department, where she completed her primary and secondary schooling. After graduation and one year in which, as she wryly put it, no hice nada 'I did nothing', she entered teacher training at the Instituto Superior Pedagógico Tupac Amaru 'Tupac Amaru Higher Institute of Pedagogy' in Tinta, another highland Cusco town (population 6000, 3500 meters altitude), graduating with her título 'title' in 1992 and taking up her first teaching post in a rural Andean community in Cusco's Espinar province.

In the ensuing years, Neri taught and increasingly also provided teacher training in various rural schools and districts throughout southern highland Peru, at first under local educational authorities of the national Ministry of Education, but later also with non-governmental organizations focusing their efforts on the improvement of education in the rural Andes at the grassroots level. Along the way, Neri earned further academic credentials pursuing studies on her own initiative, earning a bachillerato 'bachelor's degree' (1997), a segunda especialidad 'second specialization' in EIB (2004) from the Universidad Andina 
Juliaca, and completing many courses, workshops, and trainings through the years.

Neri's life trajectory and mobility mirror a path of rural to urban migration that has long been documented in Andean demographic figures and analyses (Arguedas 1966, Escobar 1972, López 1989, López \& Sichra 2008, Pozzi-Escot 1971, 1988a, b, 1989, Hornberger \& Coronel-Molina 2004, Hornberger \& King 2001) and in ethnographic and autobiographic accounts (Hornberger 1988, Coronel-Molina 2000), a path which Neri herself comments on toward the end of her interview.

Now there are many people who come from the countryside and attain a [relatively] high economic level. In Arequipa, for example, there are many people from my homeland who ... have a house, cars, everything... But the problem is that they get there and they disavow that they are Indigenous.

What is different in Neri's case, and that of most of her PROEIB peers, though, is that, contrary to the pattern she describes of leaving behind their Indigenous roots and identities, this new generation of bilingual intercultural educators consciously and intentionally hold on to a sense of Indigenous identity even as they move in urban circles and build international networks far from their rural highland roots. What had been taken for granted in her childhood has become a conscious part of her identity as a professional and transnational, globalized citizen. In order to trace the roots of this shift, I take up next Neri's experiences as a child. 
Rural/urban, Quechua/Spanish, Indigenous/Western dichotomies

Returning to Neri's narrative of the pride and confidence her father instilled in her and her sisters, she speaks on the one hand of the powerful example he set, of his skill and commitment as leader of their rural community, and his support for his daughters; and on the other, of the sense of rootedness she and her sisters developed through their frequent visits back to Callalli throughout their schooling years. Both of these experiences were, nonetheless, deeply tinged by the ever-present stereotypes and racism attached to their lives as Indigenous people.

As an example of her father's leadership, Neri described how, as alcalde 'mayor' of Callalli, he organized una marcha de sacrificio 'a sacrifice march' from Arequipa to Lima in spring of 2005 , in protest over the fact that, despite the Colca Canyon where they live being a major tourist attraction (the third most visited in Peru according to Wikipedia), no benefits or resources were being invested back into their province by the Instituto Nacional de Cultura 'National Institute of Culture' (INC), neither for the provincial capital Chivay, nor for any of the other districts including Callalli. Seven mayors made the first march to Lima but were ignored, at which point the local population, motivated by the mayors' initiative, mobilized for a strike and blocked a major bridge on the ArequipaJuliaca highway; meanwhile, her father and others went again to Lima and staged a sit-in. As a result of these actions, concessions were won. Two roads will be paved on the two sides of the Canyon and there will now be local representation in the body responsible for administering Colca Canyon tourism income. 
Neri concludes this account noting that whenever she or her mother expressed concern to their father for his safety and health in undertaking such a strenuous march at age 61, he would reply:

'Si nosotros no hacemos, ¿quién lo va hacer? Haciendo algo habrá que morirse...finalmente, algo tengo que dejar por mi pueblo.'

'If we don't do it, who will? We may as well die doing something...in the end, I have to leave something for my people.'

And she posits that this same desire to help marginalized people has been instilled in her and her sisters as they pursue their careers in bilingual intercultural education, a path their father supports materially and philosophically.

So, we are the same, no? We are on this path and believe that only social justice will in some way bring real change, after all.

A backdrop of social injustice and discrimination underlying Indigenous experience also tinges her recollections about her childhood visits to the country, here tempered by what she experienced as a natural divide between the rural and urban spaces in her growing up. She elaborates on this in relation to dress in a longer account of her and her sisters' frequent visits back to Callalli from Sicuani.

We dress in more or less western dress...since childhood. Except when we would go to my hometown... every vacation, we would always go... There we would put on our local dress - the hat, the pollera (long, traditional skirt) ... completely embroidered. ... Then our grandparents were proud ... We would 
go that way to look after the sheep and alpacas ... and we always felt good ... If we went into town with our polleras on, we would leave them there and then travel on to Sicuani in pants ... just like everyone. It seems it was completely internalized in us. Now I'm aware of it, but at that time, it was just automatic to change your clothes and go to Sicuani... That's the way it was.

Neri links wearing the pollera to being in her family's rural lands, and especially to activities and events particular to that domain, such as sheep herding. She remarks on how beautiful the clothing is and that everyone uses it there. For her and her sisters, there was a largely unproblematic, automatic association between rural place cum Indigenous dress and urban place cum Western dress.

A third pillar of this rural/urban, Indigenous/Western dichotomy was - and for many still is - language.

I think that language marks in some way... in one of my interviews with a teacher, for example, he says "when we go to a market, who speaks Quechua? It's the woman who sells herbs, let's say, or who wears a pollera, those are the ones who speak Quechua. Or those who have Indigenous appearance, Indigenous traits." So, what are Indigenous traits? It's skin color, it's a nose like this Inca one [pointing to her own], and it has a lot to do with language. The one who speaks Quechua is, automatically, rural, Indigenous.

Moreover, Neri goes on, it is the rural, Indigenous Quechua speaker, especially women and girls, who are stereotypically illiterate and uneducated, who drop out of school (traditionally taught only through the medium of Spanish), who 
cannot sign their name to vote. She recounts a poignant scene of Indigenous illiteracy from her own experience:

Who is it that doesn't know how to sign their name? It's the Indigenous person. This still exists in presidential and municipal elections... I often served as voter registration committee chair for municipal elections in Sicuani. ... A woman comes, with her pollera, her baby on her back, 'I don't know how to sign, but ñit'illasaq,' she says [in Quechua]... Nit'iy means put your fingerprint. So, she puts her fingerprint in two places, where the signature is supposed to go and where the fingerprint is supposed to go. In other words, she is illiterate, synonymous with Indigenous, no?

Neri remembers in her first teaching assignment how, although both boys and girls completed primary school in numbers nearly equal to those entering first grade, it was in the transition to secondary school that the enrollment of girls diminished, and furthermore, although 30 students might begin secondary school, by graduation just 10 would remain, and of these only 2-3 girls. More discouragingly, in her recent thesis research, she has observed a school where teachers appear to expend minimal effort to earn their paycheck, merely putting in time and showing no commitment to educate children for the future. One teacher-lawyer seems more interested in creating and promoting his political party dedicated to 'defending the peasants' than in teaching the children in his charge, and Neri asks:

How will he ever change society if, in the small space he's been given, his classroom, he can't do anything? 
As has been documented more broadly (cf. Freire 1970a, b), Indigenous illiteracy has for generations been a basis of social discrimination in the Andes, as Neri eloquently expresses:

That's where the saying comes from ... 'educated Indian, troublemaking Indian' ('indio leído, indio alzado')... Why? Because from the moment the Indigenous person arrived at school, he became conscious that he too is a person, equal to others... Indigenous people have been discriminated against...precisely... for this reason of not knowing how to read and write. That has been one of the reasons, there have been many, but that was one, a visible one.

Neri herself grew up speaking both Quechua and Spanish; as early as she can remember, she knew both. Despite his pride in their Indigenous heritage, her father used to forbid their mother speaking Quechua with the girls at home, sharing the widespread parental belief that Spanish would serve their daughters better in future social advancement, but their mother spoke it with them anyway. Schooling was in Spanish and although she saw her father write Quechua, it was only much later when she was working with the NGOs that Neri herself first learned to read and write in Quechua. With the NGO Pacha Huñuy and especially under its director Rufino Chuquimamani's strong Quechualanguage advocacy (cf. Chuquimamani 1987, 1988), she began to write in Quechua on a regular basis, for example to report on teacher training sessions she conducted (NM interview 11 Sept 2004). And it was with the NGOs that she first began to learn about and work in bilingual intercultural education, work that became the basis for her later entry into the PROEIB Maestría (NM 
interview 20 June 2005). We turn now to her experiences at PROEIB as context for exploring the ways in which her increasingly mobile professional trajectory and communicative practices contributed to her and her peers' co-construction of Indigenous identities that move beyond the taken-for-granted rural/urban, Quechua/Spanish, Indigenous/Western dichotomies to challenge deep-seated social inequalities in the Andes.

\section{PROEIB: from practice to theory}

PROEIB-Andes was founded in 1996 as a six-nation consortium effort encompassing professional development, research, knowledge management, and cooperative network-building functions in bilingual intercultural education (EIB) across the Andean countries and Latin America more generally (López, 2001, 2005, 2006; PROEIB-Andes, 2006; Sichra, 2001). At its core is the Maestría, a master's program in EIB at the University of San Simón in Bolivia enrolling Indigenous educators from Bolivia, Ecuador, Peru, Colombia, Chile, and Argentina through a selection process in each country involving their respective ministries of education, sponsoring universities, and Indigenous organizations. Applicants must be speakers of an Indigenous language who self-identify as Indigenous and are endorsed by an Indigenous community or organization. Neri's cohort of 41 included at least 10 Indigenous ethnicities and language varieties. $^{2}$

PROEIB students pursue an intense, largely westernizing academic curriculum in four areas: language, culture, education, and Indigenous language. Yet, their inand out-of-class discussions regularly contest the imposition of global, Western 
epistemologies, and each of their five 21-week semesters of coursework entails a four- to eight-week field component, culminating in extended ethnographic research for their master's theses in local sites - rural Indigenous communities and schools dispersed across all six national territories.

Neri characterizes her entry into the PROEIB Master's as a move from practice to theory. Whereas before, working in the schools, she was dedicated primarily to practice, at PROEIB she and her peers engage with theory at a deeper level than she has ever experienced before, in reading, reflection, discussion, research, and writing. Yet, it is not theory at only an abstract level divorced from practice, but theory to which they are encouraged, urged, even required to bring their own experiences, perspectives and critiques, and in particular the lens of selfconscious reflection about their own identities and practices.

Neri describes the 'digested' reading that is part of PROEIB practice:

Before I came to PROEIB, I was mainly a practitioner ... in schools ... teaching children. Also training teachers. Always in EIB, but from the point of view of practice rather than theory. Yes, I took hold of theory to ground EIB ... but it was just a little ... Now we have read more, and we have a whole different theoretical grasp, we've analyzed, we've discussed at length and each one from a different point of view... This was not superficial reading, but a more digested reading (una lectura más digerida)... that stayed with you.

She highlights the ways in which her and her peers' own experience is always called on in writing assignments, as well as in reflection on and discussion of the 
readings, characterizing this as perhaps lo más rescatable de la maestría 'the most enduring legacy of the master's program':

This does not happen in other master's programs, in other universities. Your experience is kept apart, your lived experience stays outside.... But here, in contrast ... you bring the two together, your academic life and your life, your lived experience ... you relate them to each other, recuperating what you've experienced and putting it into the academy, in effect... This is ... perhaps the most enduring legacy of the master's program.

Neri's description and characterization of reading, writing, and discussion practices resonate deeply with my own observation of PROEIB classes and of their academically demanding load of reading and writing assignments, supported by ready internet access and the resources of the PROEIB Library, probably the best collection of research on bilingual intercultural education in all of Latin America.

Perhaps even more impressive, in my observation and in Neri's account, is the deep and careful training and mentoring in ethnographic research offered by the program faculty, a training she says not only nourishes her thinking and seeing, but strengthens her Indigenous identity. To describe this research training, Neri uses the metaphor of helping a small child learn to walk by taking his or her hand and going step by step; she outlines a sequence of separate field research periods, building from strict observation to interview to autonomous choice of data collection strategies as needed. She had never done a thesis before; for her título, they did a group thesis, wherein each one contributed data but the advisor put it all together. Most master's programs she is aware of require a final 
comprehensive exam or a thesis based only on survey data. Here at PROEIB, on the other hand, learning the research process painstakingly over time taught her to see reality in a new way.

I know I still have difficulties and limitations with writing. But in the end I always feel satisfied about finishing something... because I'm learning. With all the methodology they've given us in every moment and step by step... it truly makes you see reality in a different way.

For Neri, learning to be a researcher has had a strong impact on her understanding of research and its value, but also especially on her Indigenous identity.

In these three fieldwork periods, I found many things to see and it's a great experience that nourishes my way of thinking, my way of seeing, and strengthens me as an Indigenous person. Because before, perhaps, doing research was only for high class people... lamentably, it's always been that way... In Peru, for example, there are no Indigenous researchers, researchers from rural communities...that is, even the idea of researcher isn't internalized in people's thinking... and if it were not for PROEIB, we would never have had this opportunity to do research.

The learning at PROEIB, however, goes well beyond the classroom and fieldwork experiences that are its core academic content. Neri's narrative, and my ethnographic research with her PROEIB cohort members, reveal a much deeper process of engaging in shared, border-crossing communicative and cultural practices in intentional pursuit of Indigenous identities. Their encounter with 
each other as being at once members of a shared category of Indigenous and simultaneously hailing from diverse nations, regions, and ethnicities provokes reflection on the very category of Indigeneity.

\section{A conscious Indigenous identity}

We turn now to explore aspects of the communicative and cultural practices Neri and her peers engage in, study, and advocate in their research and professional lives. Specifically, we consider Neri's personal language policy and flexible communicative practices; cultural practices as sites for sharing, contesting, negotiating Indigeneity; research and advocacy in language and cultural revitalization; and intercultural dialogue and Indigenous identity. All of these are expressions of a conscious Indigenous identity that moves well beyond the rural/urban, Indigenous/Western, Quechua/Spanish dichotomies she experienced in her childhood.

Neri's personal language policy and flexible communicative practices As an adult, Neri assumes a personal language policy of using Quechua in public, urban, and literate spaces in her daily life in a conscious effort to break down the linguistic compartmentalization of the Quechua/Spanish, rural/urban, Indigenous/Western dichotomy. She argues that the use of Quechua is a highly visible marker of Indigenous identity and that the strengthening of both depends on the daily use of Quechua as a viable language of communication.

If we don't use our language, talking on the phone, writing on the Internet, riding public transport and talking there, going to the market speaking 
Quechua, going to the supermarket and speaking Quechua, if we don't do it, who's going to do it? Language is perhaps the most noticeable, most visible, strongest marker of cultural identity.

In addition to daily use of Quechua, Neri acknowledges schooling as a transformative site for shifting the language's indexical value. She recognizes the potential of education and professional mobility as a force shifting the association between Quechua, rural life and agricultural labor, even while Quechua language use persists as indexical of a racialized Indigenous identity: There are many people in the city who are learning Quechua for employment needs. Now there are many Quechua academies in Cusco. And moreover people don't find work if they only speak Spanish.

As a student in a prestigious master's program that includes an Indigenous language requirement as a criterion for admittance, Neri is keenly aware of the benefits of a multilingual repertoire. She and her PROEIB peers see the daily use of Quechua and other Indigenous languages for ordinary communication not as dichotomized, diglossic, domain-restricted language use, but as part of a multilingual repertoire of communicative practices in multiple, scaled, polycentric spaces. Their own language and literacy practices call on them to deploy a complex and fluid set of linguistic resources as they move from everyday to academic speaking, listening, reading, and writing not only in their own Indigenous languages, but also their peers' languages, as well as varieties of Spanish and English (for more discussion of translanguaging practices in PROEIB, see Hornberger \& Swinehart 2012, Luykx et al. 2005). 
Neri's personal language policy and flexible communicative practices are reinforced in turn by her academic studies of sociolinguistics and analyses of language structure in the Indigenous Languages course, bringing a developing awareness of accent, register, dialect, and other 'bits' of language variation. She is conversant with dimensions of grammatical, lexical, and orthographic variation within Cusco Quechua and its historical evolution in connection with current, competing standardizing efforts, but she reaffirms that in revitalization, the latter efforts are secondary or complementary to actual language use. This conviction finds expression and reinforcement in cultural practices she and her peers engage in within and beyond the walls of PROEIB.

\section{Cultural practices as sites for sharing, contesting, negotiating Indigeneity}

Neri intentionally seeks opportunities with her peers to engage in local cultural practices in Cochabamba and at sites of Indigenous heritage throughout the Andes. For example, on their way to participate in a national congress on EIB in Buenos Aires in June 2004, a group of 10 PROEIB students stopped at the Argentinian border, La Quiaca, to share some of their EIB experiences in a local teachers' meeting, give a talk in the provincial capital Jujuy at the university there, and visit the pre-Columbian fortress Pucará de Tilcara near their peer René's home where they shared samples of their cultural practices, e.g. ropa típica 'typical dress' and an Abancay huayño performed by Neri. On other occasions, they have made pilgrimages across Bolivia or into Peru to celebrate specific fiestas at meaningful archaeological or religious sites. In some cases, they celebrate the pago 'payment' ceremony honoring Pachamama 'mother 
earth', performed by their classmate Jaime or by an Aymara elder they invited along; in all cases, they go to experience together important cultural practices at historically meaningful Andean sites.

Neri sees these shared border-crossing cultural experiences as valuable parts of her learning at PROEIB and is somewhat critical of her peers who choose not to participate, seeing the Maestría as nothing more than getting a credential. Far from detracting from her studies, Neri sees the pilgrimages as a significant part of their learning and mutual construction of identity:

Si tanto vale nuestra experiencia, ¿porque no construir experiencia aquí también de todo, no solo allí adentro, no solo académico, sino compartir? If our experience is so valuable, then why not construct experience here too, not just in our classes, in the academic work, but also by sharing together?

It concerns her that so many local cultural practices, and the teachings within them, are being lost; she believes that within those practices lies a rich cultural treasure. She and her peers take seriously the importance of continuing, reviving, and recording local cultural practices, including food and cooking practices they share regularly with each other from their own local traditions. These intentional practices of cultural border-crossing and co-construction fuel their continual and never fully resolved conversations, inside and outside class, about Indigeneity.

Who after all is Indigenous? Neri comments that latent racial/ethnic discrimination surfaces even among themselves at times. Someone points a 
finger at someone else for not being 'pure' Indigenous, for being too "citified". In the Indigenous Language class at one point, someone was understood to say that those who pass the English course aren't Indigenous (although he later denied having said that). Others identify themselves not as Indigenous, but Amazonian, for example; they start classifying themselves and each other or questioning each others' practices. Neri herself is not immune to these questionings and selfquestionings.

A further question arises -- how can it be that PROEIB promotes bilingual intercultural education and Indigenous identity, yet PROEIB staff members are not Indigenous themselves - and secretaries, staff, and caretakers are not speakers of any Indigenous language? It is a troubling contradiction.

We say we don't want our language to die, our culture to be lost, but yet PROEIB on the other hand is allowing people who don't know their originary language to work here... it's very hard to understand.

Yet, Neri acknowledges in the next breath that the ability to pose such questions is a direct result of the critical thinking habits they have acquired at PROEIB.

Pero también, nunca hubiéramos llegado a estos comentarios, a estas reflexiones, o a percibir cosas, nunca, si no hiciéramos la reflexión que hacemos, y no leyéramos toda la bibliografía que leemos. Nunca. No nos hubiéramos cuestionado nada.

But also, we never would have arrived at these commentaries, these reflections, never would have begun to perceive these things, if we had not 
done the reflection we do, or read all the bibliography we read. Never. We would not have questioned at all.

She emphasizes that they would have remained as they were, conforming to internalized social norms if it were not for PROEIB; and she provides a concrete example of the questioning:

Our arrival to PROEIB has meant that we are continually questioning. Ourselves, our acts, our way of saying things, of dressing, of eating, everything. At times, there are colleagues who don't want to eat a little food from the street, let's say... They'll say - No, I don't want to go to the market because it stinks there... Then, immediately someone comes out and says what kind of Indigenous person are you? It's true, just like that. And we're always in this... So, the person who hears that also says - oh, you're right. And so, he/she is obliged to reflect and the next minute says - ok, let's go. Neri's account vividly demonstrates the day-to-day construction of Indigenous identity within PROEIB, as she and her peers negotiate linguistic, cultural and intercultural practice across the urban/rural, Spanish/Quechua (Indigenous), Western/Indigenous borders so thoroughly rooted and internalized in Andean societies. It is in their quest for answers to those deep and compelling questions about Indigeneity that the role of research and advocacy comes to the fore.

\section{Neri's research and advocacy in language and cultural revitalization}

Neri focused her thesis research on language, specifically Quechua language revitalization in a peri-urban community outside Cusco. In her fieldwork, she found a series of contradictions that reinforced her sense of the need for advocacy for Quechua and other Indigenous languages. On the one hand, 
teachers lamented that Quechua was being lost, yet did not take the trouble to teach it. Parents, on the other hand, commented that their children are ashamed to speak Quechua, yet they were well aware that speaking Quechua would be advantageous for the children's future professional employment. Neri found it ironic that parents, the dueños 'owners' of the language, called for the government to do a better job of spreading the language by policy measures and media.

Imagine! He says the government should spread Quechua. And Quechua is THEIR language! He suggests that the government should disseminate through the media, radio, TV, that the authorities ought to give norms. Then I tell him -- but there is a government norm, the Law of Languages, in Peru. The Ministry of Education has a whole directorate of EIB. Nevertheless, this is not publicized - they don't even know about it. In the communities, the parents, the users of the language, the owners (dueños), I'd call them, don't even know about these laws in favor of their language... they've never heard of them. So, I too believe these norms should be better disseminated.

As Neri described her research process and how she learned to deepen her analysis and see things a new way, she narrated a conversation with her thesis adviser that complicated her perspective on the power relations involved in Indigenous language revitalization. When she remarked that she was pleased that so many parents told her in interviews that they wanted the school to teach in both Spanish and Quechua, her adviser responded, surprisingly, that that was puro discurso 'just talk,' probably at least in part directed by her questioning, and that he'd only believe they really want EIB if they told her 'we want to speak 
Quechua, only Quechua, and have our children taught only in Quechua as well -forget Spanish.' Neri goes on:

So I say, 'but Prof, you're being very extremist. Spanish also has value. It should be both. We're in a globalized world and I think both languages serve, don't they? for westerners as well as for Indigenous people.' 'Yes, but Spanish can defend itself, the language that needs defending is Quechua.' I think he's right there ... yes, it left me with a lot to ponder.

Through the research process, Neri came to a more nuanced view of Quechua language ideologies and their role in language use and revitalization. Turning the Quechua/Spanish, rural/urban, Indigenous/western contrast on its head in this way struck her at first as too 'extremist,' but it also highlighted for her the crucial roles stratified relations of power and the indexicality of language play in Indigenous language revitalization.

Another key finding from Neri's fieldwork was the close connection between language revitalization and cultural practices. She was struck by an abuelita 'grandma' who narrated a story of wedding practices in her day, using an 'exquisitely sweet' Quechua Neri fears will be lost, along with the cultural practices she described. In another moment, she mused on the traditional practices and festivities surrounding the handing on of the vara 'baton' to a newly inaugurated mayor --a ceremony tanto moderno u occidental y de la comunidad propia 'equally modern or western and the community's own,' increasingly rare but still observed in some Ollantaytambo communities. She also recalled the day she observed and participated in a faena 'communal work day' at her fieldwork site, involving all community members in replacing the 
pipes for the community's water supply. In all of these narratives, Neri remarks on the continuity and change in language and cultural practice around Indigenous tradition and worries about loss of these practices:

No one shirks their obligation, in fact. I think this is already being lost in the cities. If you don't want to go, you don't. Let's say for the school work day - I don't go and I just pay the fine. But in the community, no, everyone shows up.

Neri believes that 'devolving and protecting' Indigenous resources (Smith 1999) includes cultural practices like these, as much as language on the one hand, or natural resources and material artifacts on the other. And it is here that she encounters the significance of intercultural dialogue.

\section{Intercultural dialogue and Indigenous identity}

An agronomist came to meet with members of her research community about a training program to develop granjas 'small farms' for raising guinea pigs, chickens, cows, and pigs, part of a regional Cusco-Puno development project. Both Neri and the agronomist happened to arrived early at the meeting and struck up a conversation in Spanish about economic development and interculturality, the agronomist insisting that economic development must come first before people can think about ' 2 nd order' things like interculturality, whereas Neri sees interculturality as integral to economic development and to Indigenous presence in the city. When the agronomist found out she was doing research on bilingual intercultural education, he challenged her a bit as to how relevant interculturality could be when people are dying of hunger and their communities are disappearing as they increasingly urbanize. 
Neri insisted that interculturality is not an ideal, but lived practice. She narrates how she spoke of interculturality as cultural dialogue between cultures copresent and interwoven in the same space, co-existing not as separate, pure cultures but with mutual dialogue and respect. She gave as example an Indigenous person like herself wearing western clothes, and also told him of a family in the community that continues to observe cultural practices brought with them from their rural home in Cusco's remote Chumbivilcas province; she invited the agronomist to visit the home with her. He replied that it all seems very utopic to him. This conversation caught Neri's attention as she realized that people think of interculturality in very ideal terms, something that happens somewhere else perhaps, rather than right here in esa mezcla, ese cruce 'that mix, that crossing' of persons wherever they may be.

She observed many examples of the coexistence of rural cultural practices in her peri-urban research site. In one family from Chumbivilcas, she found that the young girls were always alert to gather firewood as they walked with her in the hills, a habit and task that is built in to the life of a rural child, but is not part of a city child's thinking. She mentions the reproduction of ways of living, cooking, keeping home, as well as customs and saint's day feasts, even the dextrous horseback riding competitions for which Canas province is famous, enacted now here in Cusco. She had not expected to see practices like these in the city. Pareciera que la gente andina del campo se va a la ciudad y reproduce lo mismo que hacía en su comunidad. ...Yo de verdad, no sé si estaba cegada para esas cosas, antes, pero ahora que vuelvo veo todo. 
It seems that Andean people from the countryside come to the city and reproduce exactly what they did in their community...Truthfully, I don't know if I was blind to these things before, but now that I've come back I see it all.

Neri was impressed by the community president's style of leadership in developing and promoting his community, a style which resonated with her as rooted in Indigenous practices and a spirit of service. Now in his third term, he had successfully negotiated the sale of trees belonging to the community, a complicated and expensive bureaucratic process involving authorization from the Ministry of Agriculture and a certifying letter from an agronomist; and he has consciously taken on responsibility for training the next generation of leaders -his vice-president is a young man of 20 . She quoted his words:

'I don't want to profit from my presidency, but to serve my people. I don't want this community to be left behind and I want it to remain a community as it has up to now, though there are many who want to urbanize it.'

The president's comment about pressures to urbanize the community points to a recurring concern in Neri's research and advocacy for interculturality as fluid dialogue among multiple, mobile, co-existing cultures. Just as rural Indigenous cultural practices increasingly make space for themselves in urban contexts, so too urban, Western practices insert themselves into Indigenous ways of life. Prominent among these is the encounter between a traditional Indigenous community-oriented service model of economic development as represented by the community president and the individualistic, western model represented by 
the agronomist and increasingly inserting itself into Indigenous thinking, as Neri vividly summarizes:

La idea occidental de economía es acumular, es tener de todo. Si, digamos, ya tengo un carro, necesito otro para mi hijo; si tengo celulares... también la empleada tiene que tener... Es... un poco exagerado, ¿no? Siempre más, más, más, más. Y si tengo una casita pequeña, tengo que ampliar y así... Yo creo que... eso ahora está entrando a la idea del indígena.

The Western idea is to accumulate, to have it all. If, let's say, I have a car, I need another one for my son; if I have mobile phones... my maid needs one too.... It's a bit exaggerated, isn't it? Always more, more, more, more. And if I have a little house, I need to expand it and so on... I believe that this is now entering into Indigenous thinking.

It concerns her that Indigenous youth are growing up in urban contexts without a conscious sense of their Indigenous roots or identity. And she advocates for consciousness-raising efforts to counter that trend.

People don't realize ... they live their lives, not aware ... of what it means to live this way. But once someone makes you think about it ... then you wake up... There may be many Indigenous people who don't know they are Indigenous ... in the cities, for example. Migrants come, their children grow up, now they think they are from Cusco... They no longer identify with their community, where their parents came from, their grandparents... Maybe they were born there, but now, they have nothing to do with their past. I say for people like that there should be some awareness-raising, maybe, of who 
we are, some recognition... do something so that they too realize that yes, they are Indigenous.

It's not that Neri rejects any and all western influences. She agrees with Linda Tuhiwai Smith's (1999) Indigenous project of critically reading Western history, but this doesn't mean that todo lo que es occidental desde la conquista hasta ahora no sirva 'everything western since the Conquest is now no good.' Rather, she emphasizes notions of diálogo 'dialogue' and encuentro 'encounter', the fluid movement, mutual respect and influence among cultures.

Bueno, ha sido un encuentro de dos mundos, de dos culturas ... pero, yo creo que debe haber consideración de ambas partes. El indígena es muy considerado pero el blanco a veces no. Entonces, yo creo que más bien se debe ... reflexionar de ambas partes. Debe haber este respeto mutuo que se pregona con interculturalidad.

Well, it has been an encounter between two worlds, two cultures... but I believe there has to be consideration on both sides. The Indigenous person is very considerate, but the white person not always. So, I believe that it would be better... for both sides to reflect. There should be that mutual respect that we talk about with interculturality.

\section{Co-constructing Indigenous identities to challenge deep-seated social inequalities: A final reflection}

Not content to live her life within the confines of long-entrenched racist stereotypes, social discrimination, and dichotomized linguistic and cultural 
practices, Neri calls insistently in her words and actions for a true intercultural relationship of equals in a mobile, globalized world. I personally find great hope in the eloquence and groundedness of her analysis, outlook, and activism toward reclaiming an Indigenous identity and future in the Andes - and in the specificity of the agenda she and her peers pursue in furthering these, namely:

1) a personal language policy and flexible communicative practices aimed toward shifting the indexical value of Indigenous languages;

2) cultural practices engaged as sites for sharing, contesting, and negotiating Indigeneity;

3) research and advocacy contributing to devolution and protection of Indigenous linguistic and cultural resources; and 4) intercultural dialogue and encounter directed at raising consciousness of Indigenous identity in mobile, globalized spaces.

Hers is not by any means a naïve or uncritical stance, nor does it represent a way of life frozen in time or place, but rather it is a set of professional and life commitments consistently practiced and generously offered to her world and our world.

References 
Arguedas, J. M. (1966). Mesa Redonda sobre el Monolingüismo Quechua y Aymara y la Educación en el Perú (Vol. 2). Lima, Peru: Casa de la Cultura.

Blommaert, J., \& Backus, A. (2011). Repertoires revisited: 'Knowing language' in superdiversity. Working Papers in Urban Language and Literacies, 67.

Blommaert, J., \& Rampton, B. (2011). Language and superdiversity. Diversities, $13(2), 1-22$.

Blommaert, J. (2010). The Sociolinguistics of Globalization. New York: Cambridge University Press.

Bourdieu, P. (1990). The Logic of Practice. Stanford: Stanford University Press. Chuquimamani Valer, N. R. (1987). Lexicon Quechua: La vida rural en Sollocota por campos semánticos.

Chuquimamani Valer, R. (1988). Una muestra del conflicto linguistico nacional en el habla de los sollocotenos: El caso del parto. In L. E. Lopez (Ed.), Pesquisas en Linguistica Andina (pp. 163-180). Lima-Puno, Peru: CONCYTEC / UNA-Puno / GTZ.

Coronel-Molina, S. (2000). Piruw malka kichwapiq hatun qillqa lulay. Amerindia. Escobar, A. (Ed.). (1972). El reto del multilingüismo en el Peru. Lima: IEP. Fairclough, N. (1992). Intertextuality in critical discourse analysis. Linguistics and Education, 4, 269-293.

Freire, P. (1970a). Pedagogy of the Oppressed. New York: Herder \& Herder. Freire, P. (1970b). The adult literacy process as cultural action for freedom. Harvard Educational Review, 40(2), 205 - 225.

Goffman, E. (1974). Frame Analysis. New York: Harper and Row. Gumperz, J. J. (1982). Discourse Strategies. Cambridge: Cambridge University Press. 
Hornberger, N. H. (1988). Bilingual Education and Language Maintenance: A Southern Peruvian Quechua Case. Berlin: Mouton.

Hornberger, N. H., \& Coronel-Molina, S. M. (2004). Quechua language shift, maintenance and revitalization in the Andes: The case for language planning. International Journal of the Sociology of Language, 167, 9-67.

Hornberger, N. H., \& King, K. A. (2001). Reversing Quechua language shift in South America. In J. A. Fishman (Ed.), Can Threatened Languages be Saved? "Reversing Language Shift" Revisited: A 21st Century Perspective (pp. 166-194). Clevedon, UK: Multilingual Matters.

Hornberger, N. H., \& Swinehart, K. F. (2012). Bilingual intercultural education and Andean Hip-hop: Transnational sites for Indigenous language and identity. Language in Society.

Howard, R. (2007). Por los Linderos de la Lengua: Ideologías Lingüísticas en los Andes. Lima, Peru: Instituto de Estudios Peruanos/Instituto Francés de Estudios Andinos, Pontificia Universidad Católica del Perú.

Hymes, D. H. (1980). Language in Education: Ethnolinguistic Essays. Washington D.C.: Center for Applied Linguistics.

Hymes, D. H. (1996). Ethnography, Linguistics, Narrative Inequality: Toward an Understanding of Voice. Bristol, PA: Taylor and Francis.

Jørgensen, J. N., Karrebaek, M. S., Madsen, L. M., \& Møller, J. S. (2011).

Polylanguaging in superdiversity. Diversities, 13(2), 23-38.

López, L. E. (1989). La política lingüística peruana y la educación de la población indígena. In L. E. López \& R. Moya (Eds.), Pueblos Indios, Estados, y Educación (pp. 133-166). Lima, Peru: PEB-Puno/PEBI (MEC-GTZ)/ERA.

López, L. E. (2001). Literacies and intercultural bilingual education in the Andes. 
In D. R. Olson \& N. Torrance (Eds.), Literacy and Social Development: The Making of Literate Societies (pp. 201-224). Malden, MA: Blackwell.

López, L. E. (2005). De Resquicios a Boquerones: La Educación Intercultural Bilingüe en Bolivia [From Fissures to Craters: Intercultural Bilingual Education in Bolivia]. La Paz: PROEIB Andes y Plural Editores.

López, L. E. (2006). Cultural diversity, multilingualism and indigenous education in Latin America. In T. Skutnabb-Kangas, O. García \& M. Torres-Guzmán (Eds.), Imagining Multilingual Schools: Languages in Education and Glocalization (pp. 238-261). Clevedon, U.K.: Multilingual Matters. López, L. E., \& Sichra, I. (2008). Intercultural bilingual education among indigenous peoples in Latin America. In J. Cummins \& N. H. Hornberger (Eds.), Encyclopedia of Language and Education, Volume 5: Bilingual Education (pp. 295-309). New York, NY: Springer Science+Business Media LLC.

Luykx, Aurolyn, Julca G., Félix, \& García Rivera, Fernando (2005). Estrategias de comunicación interdialectal en Quechua. Paper presented at the Proceedings of the Conference on Indigenous Languages of Latin America-II / Memorias del Congreso de Idiomas Indígenas de Latinoamérica-II, Organized by the Center for Indigenous Languages of Latin America (CILLA),Teresa Lozano Long Institute of Latin American Studies at the University of Texas at Austin. Pozzi-Escot, I. (1971). La educación rural en el Peru: El problema de los Quechua-hablantes. In Primer seminario de investigación y enseñanza de la lingüística (pp. 99-104). Chile: Instituto Central de Lenguas, Universidad de Concepción.

Pozzi-Escot, I. (1988a). La educación bilingüe en el Perú: Una mirada retrospectiva y prospectiva. In L. E. López (Ed.), Pesquisas en Lingüística 
Andina (pp. 37-77). Lima-Puno: CONCYTEC/Universidad Nacional del Altiplano-Puno/GTZ.

Pozzi-Escot, I. (1988b). La incomunicación verbal en el Perú. In L. E. López (Ed.), Pesquisas en Lingüística Andina (pp. 109-120). Lima-Puno, Peru: CONCYTEC/UNA-Puno/GTZ.

Pozzi-Escot, I. (1989). Reflexiones para una política nacional de lenguas y culturas en la educación, con especial referencia a las lenguas vernáculas. In L. E. López, I. Pozzi-Escot \& M. Zúñiga (Eds.), Temas de Lingüística Aplicada (pp. 21-54). Lima: CONCYTEC/GTZ.

PROEIB-Andes (2006). Interculturalidad y bilingüismo en la educación superior: Desafíos a diez años de la PROEIB Andes [Interculturality and bilingualism in higher education: Challenges as PROEIB Andes celebrates ten years]. Cochabamba, Bolivia: PROEIB Andes.

Sichra, I. (2001). Huellas de intraculturalidad en un ámbito intercultural de educación superior. In M. Heise (Ed.), Interculturalidad: Creación de un Concepto y Desarrollo de una Actitud (pp. 193-202). Lima, Peru: Programa Marco de Formación Profesional Tecnológica y Pedagógica en el Perú (FORTE-PE).

Silverstein, M. (2006). Pragmatic indexing. In K. Brown (Ed.), Encyclopedia of Language and Linguistics (Vol. 6, pp. 14-17). Amsterdam: Elsevier.

Smith, L. T. (1999). Decolonizing Methodologies: Research and Indigenous Peoples. London: Zed. [2nd edition, 2012]

* I am grateful to Luis Enrique López for inviting me to visit and collaborate with PROEIB; and to all the faculty, staff, and students at PROEIB for welcoming me to 
spend time with them. I especially thank Neri Mamani for her friendship, warmth, and generosity in sharing her views and experiences with me. I use her real name here, with her permission and encouragement. I hope that in some small way I have succeeded in conveying the depth and inspiration her life and words hold for me and for many others.

* I am grateful to Luis Enrique López for inviting me to visit and collaborate with PROEIB; and to all the faculty, staff, and students at PROEIB for welcoming me to spend time with them. I especially thank Neri Mamani for her friendship, warmth, and generosity in sharing her views and experiences with me. I use her real name here, with her permission and encouragement. I hope that in some small way I have succeeded in conveying the depth and inspiration her life and words hold for me and for many others.

${ }^{1}$ Unless otherwise indicated, all interview quotes come from my interviews with Neri on 20 and 28 June 2005. All translations are mine. Due to space restrictions, I include her original Spanish (or Quechua) in only a few instances. 2 The cohort included speakers of Quechua from Bolivia, Ecuador, and Peru; Aymara from Bolivia and Peru; Asheninka, Awajún, and Huampí from Peru; Mapuche from Chile; Cofán and Wayuú from Colombia; Shwar from Ecuador; and an Argentinian Colla from Jujuy. 